\title{
CARBON DIOXIDE SEQUESTRATION BY DIRECT MINERAL CARBONATION: PROCESS MINERALOGY OF FEED AND PRODUCTS
}

February 2001

\author{
W.K. O'Connor, D.C. Dahlin, C.L. Dahlin, and W.K. Collins \\ Albany Research Center \\ Office of Fossil Energy \\ US Department of Energy \\ 1450 Queen Ave., SW \\ Albany OR 97321
}

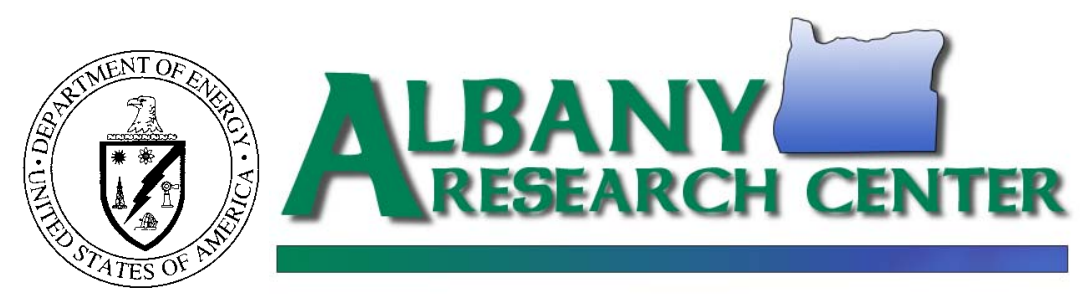

Preprint, 2001 SME Annual Meeting \& Exhibit, February 26-28, Denver Colorado 
Carbon Dioxide Sequestration By Direct Mineral Carbonation:

Process Mineralogy of Feed and Products

W.K. O€onnor, D.C. Dahlin, G.E. Rush, C.L. Dahlin, and W.K. Collins

\author{
Albany Research Center \\ Office of Fossil Energy \\ U.S. Department of Energy \\ 1450 Queen Ave SW \\ Albany, OR 97321ForF
}




\section{ABSTRACT}

Direct mineral carbonation has been investigated as a process to convert gaseous $\mathrm{CO}_{2}$ into a geologically stable final form. The process utilizes a slurry of water, with bicarbonate and salt additions, mixed with a mineral reactant, such as olivine $\left(\mathrm{Mg}_{2} \mathrm{SiO}_{4}\right)$ or serpentine $\left[\mathrm{Mg}_{3} \mathrm{Si}_{2} \mathrm{O}_{5}(\mathrm{OH})_{4}\right]$. Carbon dioxide is dissolved into this slurry, resulting in dissolution of the mineral and precipitation of magnesium carbonate $\left(\mathrm{MgCO}_{3}\right)$. Optimum results have been achieved using heat pretreated serpentine feed material and high partial pressure of $\mathrm{CO}_{2}$ $\left(\mathrm{P}_{\mathrm{CO} 2}\right)$. Specific conditions include: $155^{\circ} \mathrm{C} ; \mathrm{P}_{\mathrm{CO} 2}=185 \mathrm{~atm}$; $15 \%$ solids. Under these conditions, $78 \%$ conversion of the silicate to the carbonate was achieved in 30 minutes. Process mineralogy has been utilized to characterize the feed and process products, and interpret the mineral dissolution and carbonate precipitation reaction paths.

\section{INTRODUCTION}

The Albany Research Center (ARC) of the U.S. Dept. of Energy (DOE) has been conducting a series of mineral carbonation tests at its Albany, Oregon facility over the past 2 years as part of a Mineral Carbonation Study Program within the DOE. Other participants in this Program include the Los Alamos National Laboratory (LANL), Arizona State University (ASU), Science Applications International Corporation (SAIC), and the DOE National Energy Technology Laboratory (NETL).

Lackner, et al. $(1996,1997)$ discussed $\mathrm{CO}_{2}$ storage as mineral carbonates, although these publications describe a process that differs dramatically from the subject process. The direct mineral carbonation process utilizes a slurry of fine particle sized mineral in water, at solids concentrations from $15-30 \%$. Dissolution of the mineral and subsequent carbonation occur in a single unit operation. The theorized reaction equations follow.

$\mathrm{CO}_{2}+\mathrm{H}_{2} \mathrm{O} \rightarrow \mathrm{H}_{2} \mathrm{CO}_{3} \rightarrow \mathrm{H}^{+}+\mathrm{HCO}_{3}^{-}$

$\mathrm{Mg}_{2} \mathrm{SiO}_{4}+4 \mathrm{H}^{+} \rightarrow 2 \mathrm{Mg}^{+2}+\mathrm{H}_{4} \mathrm{SiO}_{4}$ or $\mathrm{SiO}_{2}+2 \mathrm{H}_{2} \mathrm{O}$

$\mathrm{Mg}^{+2}+\mathrm{HCO}_{3}^{-} \rightarrow \mathrm{MgCO}_{3}+\mathrm{H}^{+}$

The $\mathrm{CO}_{2}$ is dissolved in water to form carbonic acid $\left(\mathrm{H}_{2} \mathrm{CO}_{3}\right)$, which dissociates to $\mathrm{H}^{+}$and $\mathrm{HCO}_{3}{ }^{-}$(Eq. 1). The $\mathrm{H}^{+}$ion hydrolyzes the mineral, liberating $\mathrm{Mg}^{2+}$ cations and forming silicic acid or free silica and water (Eq. 2). The free $\mathrm{Mg}^{2+}$ cations react with the bicarbonate ions to form the solid carbonate (Eq. 3). A potential process flow diagram is shown in Figure 1. The process has been described in greater detail by O'Connor, et al. (1999, 2000).

Modifications to the carbonation solution chemistry

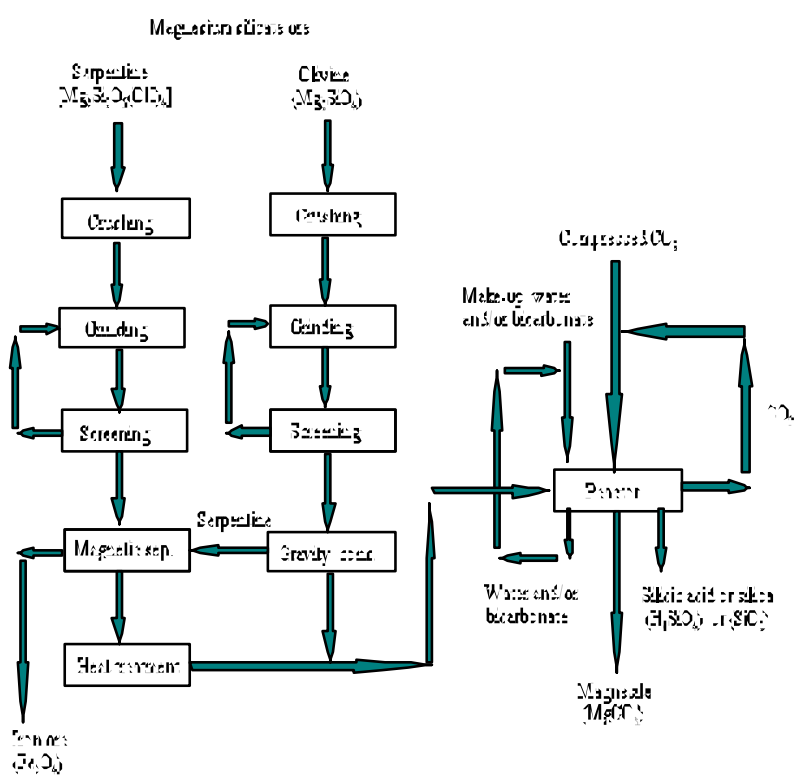

Figure 1.- Process flow diagram for the direct mineral carbonation process.

were also investigated. Additions of $\mathrm{NaHCO}_{3}$ and $\mathrm{NaCl}$ to the solution improved the reaction rate dramatically. It is theorized that the bicarbonate ion reacts with the silicate, forming the carbonate, hydroxide $\left(\mathrm{OH}^{-}\right)$ions, and free silica $\left(\mathrm{SiO}_{2}\right)$, by the following reaction (Eq. 4).

$$
\begin{aligned}
& \mathrm{Mg}_{2} \mathrm{SiO}_{4}+2 \mathrm{HCO}_{3-} \rightarrow 2 \mathrm{MgCO}_{3}+\mathrm{SiO}_{2}+2 \mathrm{OH}- \\
& \mathrm{OH}-+\mathrm{CO}_{2} \rightarrow \mathrm{HCO}_{3}-
\end{aligned}
$$

The $\mathrm{OH}^{-}$ion is believed to react immediately with the additional $\mathrm{CO}_{2}$ being injected into the solution to reform the bicarbonate (Eq. 5), maintaining a relatively constant solution chemistry. This may be described as a buffered solution. The in-situ $\mathrm{pH}$ of the solution can not be measured, but pre- and post-test $\mathrm{pH}$ measurements remain relatively constant, in the range of 7.7-8.0. This supports the assertion that the solution chemistry remains relatively constant, and verifies that the bicarbonate addition is not consumed in the reaction, but acts as a catalyst.

The direct mineral carbonation tests have focused thus far on ultramafic minerals as the primary reactants. Geologic studies by Hunter (1941), the IGCP (1977) and Goff $(1997,2000)$ indicate that reserves of these ultramafic minerals are sufficient to provide raw materials for the mineral carbonation of all annual $\mathrm{CO}_{2}$ emissions for many years. Additional studies conducted at ARC indicate that the mining and milling costs necessary to prepare the minerals for the ex-situ process would be similar to those 
in the porphyry copper mining industry, at approximately 4-5 U.S. dollars per ton. Estimates were made concerning the tonnage of silicate mineral necessary to carbonate $100 \%$ of the $\mathrm{CO}_{2}$ emissions from a single $1 \mathrm{GW}$ coal-fired power plant. Assuming a mean $\mathrm{MgO}$ content of the silicate ore of $45 \mathrm{wt}$ pct, $100 \%$ ore recovery, and $80 \%$ efficiency of the carbonation reaction, a $1 \mathrm{GW}$ coal-fired power plant generating approximately $20 \mathrm{kt} /$ day $\mathrm{CO}_{2}$ would require over $40 \mathrm{kt} /$ day of ore.

\section{MATERIALS}

Several magnesium silicate minerals are suitable for the ex-situ carbonation reaction, including serpentine $\left[\mathrm{Mg}_{3} \mathrm{Si}_{2} \mathrm{O}_{5}(\mathrm{OH})_{4}\right]$, enstatite $\left(\mathrm{MgSiO}_{3}\right)$, and olivine, which actually represents a mineral group encompassing the solid-solution series between magnesium-rich (forsterite, $\mathrm{Mg}_{2} \mathrm{SiO}_{4}$ ) and iron-rich (fayalite, $\mathrm{Fe}_{2} \mathrm{SiO}_{4}$ ) end members. Each of these minerals occurs in ultramafic complexes, several of which are well documented in North America. Serpentine is an alteration product of olivine and other magnesium silicates, and occurs in huge deposits on both the east and west coasts of North America (Goff, et al., 1997). Olivine, particularly the forsterite end member, is also found in huge deposits on both coasts (Hunter, 1941; IGCP, 1977), although not to the extent of serpentine. Both minerals constitute potential feedstocks for the mineral carbonation process, but a magnesium silicate mineral of high purity, low water content, and high $\mathrm{MgO}$ concentration is preferred. Because serpentine is a hydrated mineral and has a lower molar concentration of $\mathrm{MgO}$ than olivine, the latter mineral was selected for the initial series of direct carbonation tests.
Following these tests, during which basic reaction parameters were established, serpentine was included. Heat pretreatment, necessary to remove the chemicallybonded water from the serpentine, was found to activate the mineral, resulting in a reaction rate exceeding that for olivine. However, the energy demand may preclude heat treatment, thus alternative means to activate the serpentine are under investigation. The chemical compositions of the typical olivine, serpentine, and heat treated serpentine head samples are included in Table I.

Magnesium oxide content in the olivine and serpentine head samples were measured at 49.7 weight percent (wt pct) and $40.8 \mathrm{wt}$ pct, respectively. The difference is attributable to the high concentration of chemicallybonded water ( $13.6 \mathrm{wt} \mathrm{pct})$ in the serpentine. The serpentine was heat treated for 2 hours at $630^{\circ} \mathrm{C}$ to remove the water, resulting in a subsequent increase in magnesium oxide content to 45.7 wt pct. Emphasis is placed on the magnesium oxide concentration of the feed material, because it is this oxide that reacts with the carbon dioxide to form the carbonate. Thus, feed materials with higher magnesium oxide concentration are preferred. Calculation of the extent of reaction for the direct carbonation tests was based on the concentration of magnesium oxide in the feed, and the stoichiometry of the following theoretical equations.

$\mathrm{Mg}_{2} \mathrm{SiO}_{4}+2 \mathrm{CO}_{2} \rightarrow 2 \mathrm{MgCO}_{3}+\mathrm{SiO}_{2}$

$\mathrm{Mg}_{3} \mathrm{Si}_{2} \mathrm{O}_{5}(\mathrm{OH})_{4}+3 \mathrm{CO}_{2} \rightarrow 3 \mathrm{MgCO}_{3}+2 \mathrm{SiO}_{2}+2 \mathrm{H}_{2} \mathrm{O}(7)$

Table I. Chemical Composition of the Feed and Products (wt pct)

\begin{tabular}{|c|c|c|c|c|c|c|c|c|c|}
\hline Oxide & $\begin{array}{c}\text { Olivine } \\
\text { (forsterite) } \\
\end{array}$ & Serpentine & $\begin{array}{c}\text { Heat treated } \\
\text { serpentine }\end{array}$ & $\begin{array}{c}\mathrm{SC}-4 \\
\text { product }\end{array}$ & $\begin{array}{c}\mathrm{SC}-11 \\
\text { product }\end{array}$ & $\begin{array}{c}\mathrm{SC}-25 \\
\text { product }\end{array}$ & $\begin{array}{c}\mathrm{SC}-39 \\
\text { product }\end{array}$ & $\begin{array}{c}\mathrm{SC}-40 \\
\text { product }\end{array}$ & $\begin{array}{c}\mathrm{SC}-84 \\
\text { product }\end{array}$ \\
\hline $\mathrm{Al}_{2} \mathrm{O}_{3}$ & 0.208 & 0.167 & 0.270 & 0.171 & 0.149 & 0.171 & 0.196 & 0.132 & 0.180 \\
\hline $\mathrm{CaO}$ & 0.070 & 0.077 & 0.146 & 0.155 & 0.155 & 0.230 & 0.356 & 0.231 & 0.022 \\
\hline $\mathrm{Cr}_{2} \mathrm{O}_{3}$ & 0.044 & NA & NA & NA & NA & NA & NA & 0.247 & NA \\
\hline $\mathrm{FeO}$ & 5.966 & 3.497 & 3.394 & 5.953 & 6.223 & 5.271 & 0.386 & 8.576 & 2.649 \\
\hline $\mathrm{Fe}_{2} \mathrm{O}_{3}$ & 2.558 & 3.272 & 4.544 & NA & 0.029 & NA & 4.973 & $<0.010$ & 3.301 \\
\hline $\mathrm{MgO}$ & 49.677 & 40.842 & 45.676 & 41.675 & 40.508 & 35.507 & 33.673 & 36.841 & 27.672 \\
\hline $\mathrm{K}_{2} \mathrm{O}$ & 0.007 & 0.003 & 0.004 & NA & NA & NA & 0.006 & 0.005 & 0.006 \\
\hline $\mathrm{SiO}_{2}$ & 41.357 & 36.214 & 40.500 & 33.214 & 32.571 & 26.786 & 28.701 & 26.357 & 29.786 \\
\hline $\mathrm{Na}_{2} \mathrm{O}$ & 0.099 & 0.010 & 0.010 & NA & NA & NA & 0.414 & 0.144 & 0.492 \\
\hline \multicolumn{10}{|l|}{ Volatiles } \\
\hline $\mathrm{C}, \mathrm{CO}_{2}$ & $<0.300$ & 0.460 & 0.290 & 17.700 & 19.800 & 32.300 & 28.071 & 29.800 & 24.700 \\
\hline $\mathrm{C}$, fixed & 0.021 & 0.020 & 0.017 & 0.033 & 0.060 & 3.691 & 0.584 & 0.213 & 0.014 \\
\hline $\mathrm{H}_{2} \mathrm{O}^{1}$ & 0.380 & 0.310 & 0.680 & NA & NA & NA & 0.200 & $<0.050$ & 0.700 \\
\hline $\mathrm{H}_{2} \mathrm{O}^{2}$ & 0.000 & 13.610 & 3.203 & NA & NA & NA & 1.516 & 0.687 & 2.886 \\
\hline Total & 100.387 & 98.482 & 98.734 & 98.902 & 99.496 & 103.956 & 98.575 & 100.487 & 92.407 \\
\hline
\end{tabular}

\footnotetext{
${ }^{1}$ Water of dehydration (free moisture).
}

${ }^{2}$ Chemically-bonded (interstitial) water.

NA: Not analyzed 


\section{EXPERIMENTAL PROCEDURES}

The initial proof-of-concept tests were conducted in an autoclave with continuous agitation or stirring, while process parameters were monitored and recorded in real time. The stirred-tank-reactor (STR) was prepared for operation by the following procedure.

1. $100 \mathrm{~g}$ of olivine weighed and placed in the STR;

2. $400 \mathrm{ml}$ of distilled water poured into the STR;

3. the STR sealed, evacuated, weighed (tare weight), and placed into an ice bath;

4. liquid $\mathrm{CO}_{2}$ introduced into STR;

5. the STR placed back on the scale, weight of $\mathrm{CO}_{2}$ determined;

6. pressure bled off while STR on scale until proper weight of $\mathrm{CO}_{2}$ remained;

7. STR heated to final process temp. and pressure;

8. after specified test time, STR cooled, pressure bled off, slurry removed;

9. slurry filtered, solids dried, weighed, and sampled for analyses, solution sampled for analyses.

The proper weight of $\mathrm{CO}_{2}$ was calculated in advance using the compressibility factor equation of state.

$$
P \widehat{V}={ }_{R} R T
$$

\section{Where}

$P=$ pressure, atm

$\widehat{V}=$ molar volume, moles / liter

$z=$ compressibility factor for $\mathrm{CO}_{2}$

$R=$ gas constant, liter $\cdot$ atm $\cdot$ mole $e^{-1} \cdot K^{-1}$

$T=$ temperature, $K$

The solubility of $\mathrm{CO}_{2}$ in water at the desired conditions was also included in the final calculation. A detailed description of the procedure is included in a previous paper (O’Connor et al., 1999).
Following the initial test series, a new autoclave system (STR) was developed including a $\mathrm{CO}_{2}$ gas booster pump controlled by a pressure transducer on the autoclave. The modified test procedure follows.

1. $167 \mathrm{~g}$ of mineral reactant and $950 \mathrm{~g}$ of distilled water (or bicarbonate/salt solution) poured into the STR;

2. STR sealed, purged with $\mathrm{CO}_{2}$, stirrer speed 1,000 rpm;

3. STR heated to final operating temperature, stirrer speed increased to 2,000 rpm;

4. $\mathrm{CO}_{2}$ injected to final operating pressure;

5. additional $\mathrm{CO}_{2}$ injected as system pressure decreases due to chemical reaction and/or pressure leaks;

6. after specified test time, STR cooled, pressure bled off, slurry removed;

7. slurry filtered, solids dried, weighed, and sampled for analyses, solution sampled for analyses.

All tests conducted in the new system followed this simplified procedure. The inclusion of the gas booster pump permitted operation under relatively constant $\mathrm{P}_{\mathrm{CO} 2}$, which was not possible in the former system. This minimized the impact of decreasing $\mathrm{P}_{\mathrm{CO} 2}$ on reaction rate and final extent of reaction.

\section{EXPERIMENTAL RESULTS}

\section{Olivine Carbonation}

The initial series of olivine carbonation tests included no pretreatment options, other than size reduction to the desired particle size. These tests, exploratory in nature, were intended to produce a baseline set of test parameters for the carbonic acid process, utilizing distilled water as the liquid medium and continuous agitation of the slurry. Extent of reactions achieved in 24 hour and 48 hour duration tests were 52 and $56 \%$ stoichiometric, respectively (Table II, tests $\mathrm{SC}-4$ and 11). The extent of reaction, and possibly the reaction rate, decreased with decreasing $\mathrm{P}_{\mathrm{CO} 2}$. The addition of gas dispersion in the water column, and the ability to operate

Table II. Test Summaries for the Direct Mineral Carbonation Tests

\begin{tabular}{|c|c|c|c|c|c|c|c|}
\hline \multirow{2}{*}{ Test } & \multirow{2}{*}{$\begin{array}{c}\text { Feed } \\
\text { material }\end{array}$} & \multirow{2}{*}{$\begin{array}{l}\text { Particle } \\
\text { size, } \mu \mathrm{m}\end{array}$} & \multicolumn{3}{|c|}{ Carbonation conditions } & \multirow{2}{*}{ Solution chemistry } & \multirow{2}{*}{$\begin{array}{l}\text { Percent } \\
\text { stoich. }\end{array}$} \\
\hline & & & Time, $\mathrm{hr}$ & $\mathrm{T},{ }^{\circ} \mathrm{C}$ & $\mathrm{P}_{\mathrm{CO} 2}$, atm & & \\
\hline $\mathrm{SC}-4$ & olivine & $53 \times 37$ & 24 & 185 & 115 & distilled water & 52 \\
\hline SC-11 & olivine & $53 \times 37$ & 48 & 185 & 115 & distilled water & 56 \\
\hline $\mathrm{SC}-25$ & olivine & -37 & 24 & 185 & 115 & distilled water & 91 \\
\hline $\mathrm{SC}-39$ & serpentine $^{1}$ & -37 & 6 & 185 & 115 & $0.5 \mathrm{M} \mathrm{NaHCO}_{3}, 1 \mathrm{M} \mathrm{NaCl}$ & 83 \\
\hline $\mathrm{SC}-40$ & olivine & -37 & 6 & 185 & 115 & $0.5 \mathrm{M} \mathrm{NaHCO}_{3}, 1 \mathrm{M} \mathrm{NaCl}$ & 84 \\
\hline $\mathrm{SC}-84$ & serpentine $^{1}$ & -37 & 0.5 & 155 & 185 & $0.64 \mathrm{M} \mathrm{NaHCO}_{3}, 1 \mathrm{M} \mathrm{NaCl}$ & 78 \\
\hline
\end{tabular}

\footnotetext{
${ }^{1}$ Heat treated serpentine.
} 
at constant $\mathrm{P}_{\mathrm{CO} 2}$ (in the new autoclave system), resulted in significant improvement in the extent of reaction. This culminated in 91 pct stoichiometric conversion of the silicate to the carbonate in 24 hours, at a temperature of $185^{\circ} \mathrm{C}$ and $\mathrm{P}_{\mathrm{CO} 2}$ of 115 atm (Table II, test SC-25). Formation of the carbonate was confirmed by the identification of magnesite $\left(\mathrm{MgCO}_{3}\right)$ in the reaction products by X-ray diffraction (XRD) analysis (Table III).

\section{$\underline{\text { Serpentine Carbonation }}$}

During investigations conducted on naturally occurring serpentine, it was demonstrated that heat treating the serpentine, to remove chemically-bonded water and activate the mineral, improved the carbonation results (Table II, tests SC-39 and 84). The reaction rate for serpentine carbonation has been continuously improved by slight reduction of the reaction temperature, increases in the $\mathrm{P}_{\mathrm{CO} 2}$, and additional modifications of the solution chemistry. The optimum reaction conditions identified to date for heat treated serpentine include a sodium bicarbonate and sodium chloride solution chemistry, and reaction temperature of $155^{\circ} \mathrm{C}$ at a $\mathrm{P}_{\mathrm{CO} 2}$ of $185 \mathrm{~atm}$. These conditions resulted in serpentine carbonation to approximately $78 \%$ of the stoichiometric maximum in 0.5 hours (Table II, test SC-84). Magnesite was again identified by XRD as the primary phase in the reaction products (Table III).

Table III. X-ray Diffraction Analyses for the Feed and Products

\begin{tabular}{|c|c|c|c|c|c|}
\hline Test & Material & Primary & Secondary & Minor & Trace \\
\hline \multirow[t]{2}{*}{ SC-4 } & olivine head & forsterite $\left(\mathrm{Mg}_{2} \mathrm{SiO}_{4}\right)$ & & enstatite $\left(\mathrm{MgSiO}_{3}\right)$ & \\
\hline & carbonation product & magnesite $\left(\mathrm{MgCO}_{3}\right)$ & forsterite & & enstatite \\
\hline \multirow[t]{4}{*}{$\mathrm{SC}-11$} & olivine head & forsterite & & enstatite & \\
\hline & $+30 \mu \mathrm{m}$ product & forsterite & & enstatite & \\
\hline & $30 \times 10 \mu \mathrm{m}$ product & forsterite & & & magnesite, enstatite \\
\hline & $-10 \mu \mathrm{m}$ product & magnesite & & & forsterite \\
\hline \multirow[t]{2}{*}{$\mathrm{SC}-25$} & olivine head & forsterite & & enstatite & \\
\hline & carbonation product & magnesite & & & forsterite, enstatite \\
\hline \multirow[t]{3}{*}{ SC-39 } & serpentine head & $\begin{array}{c}\text { antigorite } \\
{\left[\mathrm{Mg}_{3} \mathrm{Si}_{2} \mathrm{O}_{5}(\mathrm{OH})_{4}\right]}\end{array}$ & & $\begin{array}{c}\text { clinochrysotile } \\
{\left[\mathrm{Mg}_{3} \mathrm{Si}_{2} \mathrm{O}_{5}(\mathrm{OH})_{4}\right]}\end{array}$ & $\begin{array}{c}\text { magnetite }\left(\mathrm{Fe}_{3} \mathrm{O}_{4}\right) \\
\text { clinochlore } \\
\left(\mathrm{Mg}_{5} \mathrm{Al}_{2} \mathrm{Si}_{3} \mathrm{O}_{14} \cdot 4 \mathrm{H}_{2} \mathrm{O}\right)\end{array}$ \\
\hline & heat treat product & forsterite & & $\begin{array}{l}\text { magnetite } \\
\text { antigorite }\end{array}$ & \\
\hline & carbonation product & magnesite & & & $\begin{array}{l}\text { magnetite } \\
\text { forsterite } \\
\text { antigorite } \\
\end{array}$ \\
\hline \multirow[t]{2}{*}{$\mathrm{SC}-40$} & olivine head & forsterite & & enstatite & \\
\hline & carbonation product & magnesite & & forsterite & $\begin{array}{c}\text { enstatite } \\
\text { antigorite (?) }\end{array}$ \\
\hline \multirow[t]{3}{*}{ SC-84 } & serpentine head & antigorite & & clinochrysotile & $\begin{array}{l}\text { magnetite } \\
\text { clinochlore }\end{array}$ \\
\hline & heat treat product & forsterite & & $\begin{array}{l}\text { magnetite } \\
\text { antigorite }\end{array}$ & \\
\hline & carbonation product & magnesite & & & $\begin{array}{l}\text { magnetite } \\
\text { forsterite }\end{array}$ \\
\hline
\end{tabular}

Primary phase: $40-100 \%$ Secondary phase: $20-60 \%$

Minor phase: $5-30 \% \quad$ Trace phase: $0-10 \%$

\section{ANALYSIS AND DISCUSSION OF RESULTS}

Chemical analyses were acquired for the solid products from each of the carbonation tests, and are reported in Table I. The $\mathrm{CO}_{2}$ concentration in the products, coupled with the identification of magnesite by $\mathrm{XRD}$, provided conclusive evidence that the mineral carbonation process was successful. However, understanding the pathway to this final product required further characterization. Several key questions were unanswered, such as: (1) does the conversion of the silicate to carbonate occur in the solid state; (2) what is the primary mechanism for carbonate formation; (3) what intermediate products occur; (4) is the reaction strictly surface controlled, or diffusion limited; (5) is the reaction inhibited by the formation of passive coatings on the particles; and (6) what is the fate of the silica? 
Samples of the product solids were prepared for examination with the scanning electron microscope (SEM) with wavelength-dispersive X-ray microanalysis (WDX). The results from the SEM studies provide insight regarding the reaction pathways that occur in the direct mineral carbonation process, and answers to several of the questions posed above. An examination of specific test products led to an improved understanding of the reaction pathway, although the results are not yet definitive. The discussion is grouped by carbonation test.

\section{$\underline{\text { SC-4 Olivine Reaction Products }}$}

The product solids from carbonation test SC-4 are depicted in Figure 2, which includes a backscatterelectron (BSE) image (2a) and X-ray maps for $\mathrm{Si}, \mathrm{Mg}$, and $\mathrm{O}$ (2b, 2c, and 2d, respectively). Although the X-ray maps are elemental, it is assumed that they are representative of the oxide species, unless otherwise noted. The majority of the large particles were identified as forsterite, with a few enstatite grains, reflective of the concentrations for these phases identified by XRD (Table III). The finegrained $(<10 \mu \mathrm{m})$ particles dispersed throughout the mount were identified as magnesite by SEM-WDX. This is clearly indicative of carbonate precipitation, rather than solid-state conversion, as the predominate mechanism for carbonate formation. Comparison of the X-ray maps for $\mathrm{Mg}$ and $\mathrm{O}$ with the BSE image show that the majority of the fine particles include $\mathrm{Mg}$ and $\mathrm{O}$ but $\mathrm{Si}$ is virtually absent. This is significant when considering the final fate of the silica originating from the silicate mineral. The silica

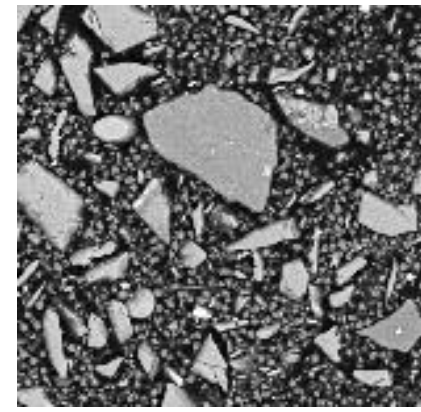

Figure 2a. BSE Image of SC4 Product $(1,500 \mathrm{x})$.

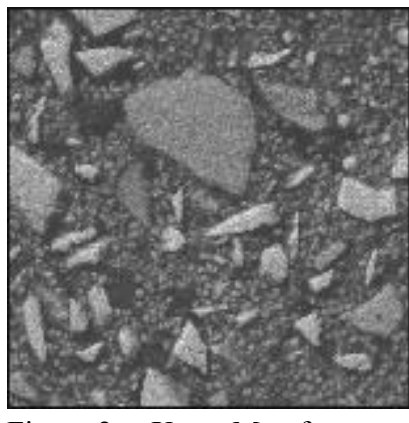

Figure 2c. X-ray Map for $\mathrm{Mg}$ on SC-4 Product.

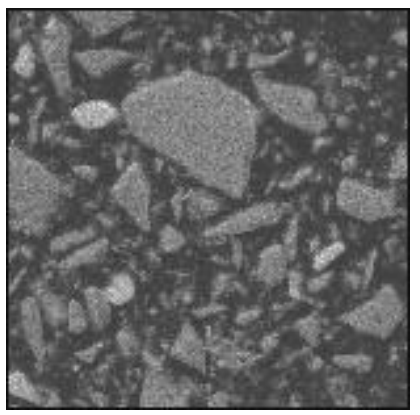

Figure 2b. X-ray Map for $\mathrm{Si}$ on SC-4 Product.

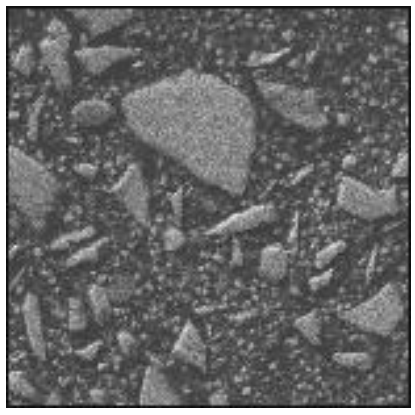

Figure 2d. X-ray Map for $\mathrm{O}$ on SC-4 Product. does not appear to agglomerate with or precipitate onto the magnesite particles.

\section{SC-11 Olivine Reaction Products}

The effect of silica transport on the reaction rate can be significant. The concentration of free silica increases with increased extent of reaction, thus, the fate of this silica is important. Figure 2 suggests that silica does not accumulate in the magnesite precipitate, so what is the fate of the silica? Residual silica may not be transported at all. This would result in silica-enriched zones (as the $\mathrm{Mg}^{2+}$ cation is removed) within the original silicate grains. The series of photomicrographs in Figure 3, including a BSE image (3a) and X-ray maps for $\mathrm{Si}, \mathrm{Fe}$, and $\mathrm{Mg}$ (3b, 3c, and $3 \mathrm{~d}$, respectively) provide insight regarding the silica occurrence in the reaction products.

The Si X-ray map clearly shows a bright border on the surface of and lining the cracks within the silicate particle. This suggests that a silica-rich layer coats the reactive surface, possibly inhibiting further dissolution. Armoring of the silicate particles by a silica-rich layer could slow further chemical attack, and suggests that the reaction may be diffusion limited.

The Fe and Mg X-ray maps clearly show two distinct zones withing the silicate particle. Figure $3 c$ shows (1) an Fe rich zone (bright white dots ), and (2) an Fe depleted zone (black areas of particle). Figure $3 \mathrm{~d}$ shows that the $\mathrm{Mg}$ concentration in the same two zones mirrors that of the $\mathrm{Fe}$, with high $\mathrm{Mg}$ concentration in the bright white

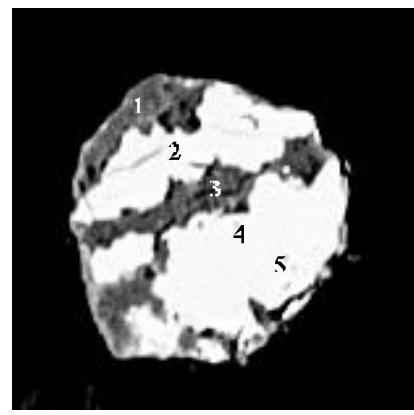

Figure 3a. BSE Image of SC11 Product $(2,000 x)$.

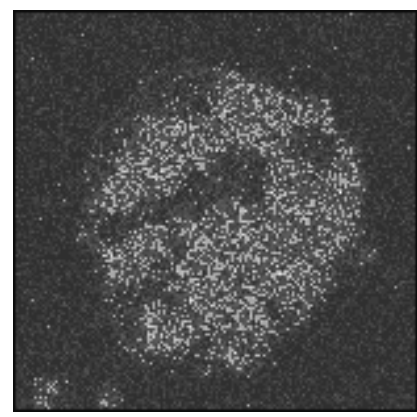

Figure 3c. X-ray Map for Fe on SC-11 Product.

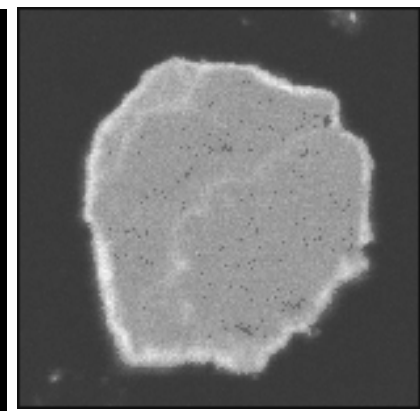

Figure 3b. X-ray Map for $\mathrm{Si}$ on SC-11 Product.

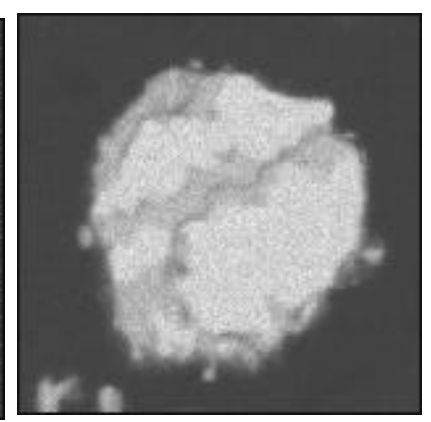

Figure 3d. X-ray Map for Mg on SC-11 Product. 
zones. This could be indicative of alteration. Removal of $\mathrm{Fe}^{2+}$ and $\mathrm{Mg}^{2+}$ cations by the carbonation solution could explain the disparity in concentration of these two metals between the two zones. The Si X-ray map shows a relatively uniform Si concentration throughout the particle, suggesting that the cations are removed without mobilization of the silica. A series of point scans, numbered 1-5 on Figure 3a, were compiled to examine the concentration of $\mathrm{Fe}, \mathrm{Mg}, \mathrm{O}$, and $\mathrm{Si}$ in these distinct zones (Table IV).

Table IV. SEM-WDX Microanalyses for SC-11 Product

\begin{tabular}{||c|c|c|c|c|c||}
\hline \multirow{2}{*}{ Point } & \multicolumn{5}{|c||}{ Atomic percent } \\
\cline { 2 - 6 } & $\mathrm{Fe}$ & $\mathrm{Mg}$ & $\mathrm{O}$ & $\mathrm{Si}$ & $\mathrm{Mg} / \mathrm{Si}$ \\
\hline \hline 1 & $\mathrm{ND}$ & 17 & 65 & 17 & 1.0 \\
\hline 2 & 1.5 & 26 & 59 & 13 & 2.0 \\
\hline 3 & $\mathrm{ND}$ & 19 & 66 & 15 & 1.3 \\
\hline 4 & 2 & 26 & 59 & 13 & 2.0 \\
\hline 5 & 2 & 26 & 59 & 13 & 2.0 \\
\hline \hline Fo & 0 & 28.6 & 57.1 & 14.3 & 2.0 \\
\hline En & 0 & 20 & 60 & 20 & 1.0 \\
\hline \hline
\end{tabular}

ND: Not detected

Theoretical compositions for forsterite (Fo) and enstatite (En) are included in the table. Points 2, 4, and 5 have a $\mathrm{Mg} / \mathrm{Si}$ ratio of $2: 1$, equal to that of forsterite, the primary feed mineral. These portions of the grain, which essentially appear free of fractures and isolated from the outer surface, have apparently undergone little or no alteration. However, points 1 and 3 have much lower $\mathrm{Mg} / \mathrm{Si}$ ratios of 1:1 and 1.3:1, respectively. Are the zones corresponding to points 1 and 3, which occur at the particle surface and/or along fractures within the particle, indicative of alteration? Or could this two-phase grain be an unaltered fragment of the feed?

Examination of the olivine feed for test SC-11 does identify similar two-phase, forsterite-enstatite grains. Iron content is lower in the enstatite compared to the forsterite as well. However, the complete absence of $\mathrm{Fe}$ in the zones corresponding to points 1 and 3 (Figure $3 a$ ) is unusual, and argues the point that some alteration is evident. Examination of reaction products from tests with greater extent of reaction than test SC-11 (56\% stoichiometric conversion) is necessary in order to more positively identify the alteration products.

Test SC-11 was a 48 hour test. This longer duration test time was apparently sufficient for the magnesite

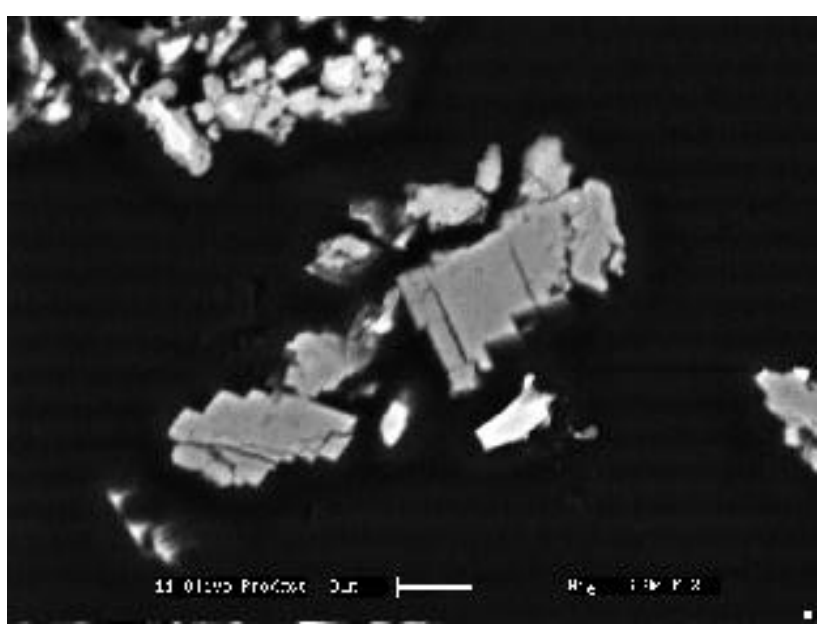

Figure 4. Rhombohedral Magnesite in SC-11 Product.

crystals to grow into their characteristic rhombohedral structure, typical of the carbonate minerals (Figure 4). This rhombohedral structure was not found in the reaction products for shorter duration tests. XRD analyses conducted on size fractions of the SC-11 product (table 3) identified magnesite as a primary phase only in the minus $10 \mu \mathrm{m}$ fraction. This size limitation appears to be universal, and independent of the length of the carbonation test. Further study is required.

\section{$\underline{\text { SC-39 Serpentine Reaction Products }}$}

The character of the magnesite product does not appear to change with increasing extent of reaction. However, alteration of the original silicate mineral is much more pronounced. The reaction products from test SC-39, which achieved $83 \%$ stoichiometric conversion of heat pretreated serpentine to carbonate, are depicted in Fig. 5.

The large grain in the center of Figure 5a shows a definite alteration rim. The X-ray maps suggest that this alteration rim is depleted in $\mathrm{Mg}(5 \mathrm{c})$, compared to the core of the grain. The Si concentration appears to be uniform throughout the grain (5d), suggesting that as the $\mathrm{Mg}^{2+}$ is removed, the silica is not mobilized, producing a zone enriched in silica. The grain provides strong evidence for a shrinking core model for the reaction.

The large skeletal grain at lower left-center in Figure 5a is composed primarily of silica. SEM-WDX microanalysis conducted on this grain reported a $\mathrm{Mg} / \mathrm{Si}$ ratio of $3: 4$. This is half the theoretical $\mathrm{Mg} / \mathrm{Si}$ ratio of 3:2 for serpentine, and lower than the theoretical ratios for either forsterite or enstatite, This grain could represent the primary fate of the silica, which may form masses of amorphous silica making up the matrix of the highly altered silicate grains. The Si X-ray map (5d) shows that fine particles $(<10 \mu \mathrm{m})$ composed primarily of silica do 


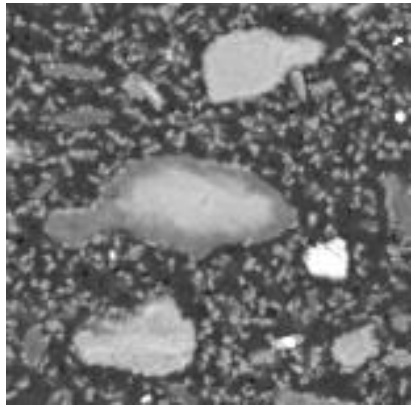

Figure 5a. BSE Image of SC-

39 Product $(1,000 \mathrm{x})$.

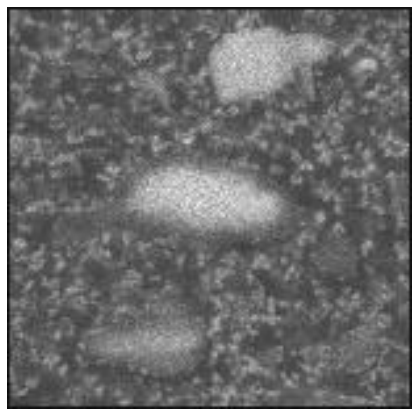

Figure 5c. X-ray map for

$\mathrm{Mg}$ on SC-39 Product.

occur, but are angular in

shape compared to the more rounded magnesite particles. This may be due to attrition of the larger skeletal grains, rather than precipitation from solution. The latter would likely result in the formation of silica gel, which would make filtration difficult. However, filtration rates of the product slurry have exceeded the rates that would be expected from a silica gel-bearing slurry, suggesting that the silica is not dissolved.

The Fe X-ray map (5b) shows that the fine magnesite particles are virtually devoid of any Fe, which differs somewhat from the magnesite produced from the olivine feed. Most of the iron oxide contained in the serpentine feed is in the form of magnetite, which appears to remain relatively inert in the carbonation reaction.

\section{$\underline{\text { SC-40 Olivine Reaction Products }}$}

Test SC-40 achieved virtually the identical extent of reaction, $83 \%$ stoichiometric, as test SC-39, although the latter utilized heat treated serpentine as the feed rather than olivine. Test conditions were held constant between the two tests, thus, it may be assumed that the heat treatment step successfully produced an olivine-like feed material from the serpentine. This is supported by the XRD analyses (Table III), which identified forsterite as the primary phase in the heat treated serpentine product. This being said, the SC-40 reaction products should closely resemble those from SC-39.

Figure 6 is a BSE image of the SC-40 reaction product.

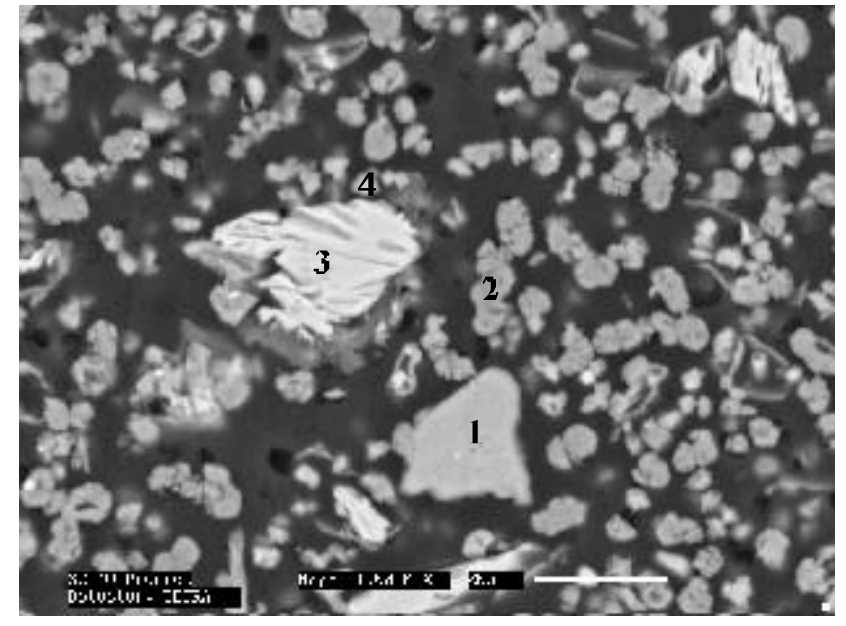

Figure 6. BSE Image of the SC-40 Product.

The small $(<10 \mu \mathrm{m})$ rounded particles dispersed throughout the view were identified as magnesite by SEM-WDX. The composition of the larger grains in the view were of significant interest. A series of SEM-WDX point scans, numbered 1-4 on Figure 6, were collected to determine the $\mathrm{C}, \mathrm{Fe}, \mathrm{Mg}, \mathrm{O}$, and $\mathrm{Si}$ concentration in the various particles (Table V).

Table V. SEM-WDX Microanalyses for SC-40 Product.

\begin{tabular}{||c||c|c|c|c|c|c||}
\hline \multicolumn{1}{||c||}{ Point } & \multicolumn{5}{|c||}{ Atomic percent } \\
\cline { 2 - 8 } & $\mathrm{C}$ & $\mathrm{Fe}$ & $\mathrm{Mg}$ & $\mathrm{O}$ & $\mathrm{Si}$ & $\mathrm{Mg} / \mathrm{Si}$ \\
\hline \hline 1 & 3 & 0.3 & 20 & 63 & 13 & 1.5 \\
\hline 2 & 26 & $\mathrm{ND}$ & 17 & 55 & 1 & 17 \\
\hline 3 & 3 & 1.3 & 25 & 58 & 12 & 2.1 \\
\hline 4 & 6 & 0.3 & 1 & 67 & 26 & 0.04 \\
\hline
\end{tabular}

ND: Not detected

The analysis for point 1 suggests that this is an altered olivine grain, depleted in $\mathrm{Mg}$, as indicated by the lower $\mathrm{Mg} / \mathrm{Si}$ ratio, 3:2 compared to that for forsterite, 2:1. Point 2 provides a typical analysis for the magnesite particles. Silica content is very low, based on the $\mathrm{Si}$ analysis for point 2, which supports the assertion made previously that silica does not report to the magnesite particles to any significant degree. The analysis for point 3 indicates that the bright white grain is relatively unaltered olivine, at least at the core of the grain. A reaction rim extremely depleted in $\mathrm{Mg}$ is obvious at the lower portion of the grain. The grain represented by point 4 is composed primarily of silica, indicative of the separate magnesite and silica particles that appear to make up the fine matrix of the sample. These small $(5-10 \mu \mathrm{m})$ silica particles may result from attritioning of the coarser, skeletal grains of altered silicate described previously in the SC-39 products. 


\section{CONCLUSIONS}

An aqueous process for the direct carbonation of silicate minerals has been developed as a method for $\mathrm{CO}_{2}$ storage in solid form. Reaction rates have been improved by utilization of supercritical $\mathrm{CO}_{2}$, at $\mathrm{P}_{\mathrm{CO} 2}$ of $115-185 \mathrm{~atm}$, temperatures of $155-185^{\circ} \mathrm{C}$, and a solution chemistry including sodium bicarbonate and sodium chloride. Up to $78 \%$ stoichiometric conversion of the silicate mineral to the carbonate has been achieved in 30 minutes under these conditions. The carbonation reaction product consists essentially of magnesite ( $\sim 60 \mathrm{wt}$ pct), free silica ( $\sim 25 \mathrm{wt}$ pct), and residual silicate $(\sim 15 \mathrm{wt}$ pct). Potential uses for the magnesite/silica product include soil amendments, replacing materials such as lime $(\mathrm{CaO})$, limestone $\left(\mathrm{CaCO}_{3}\right)$, and/or dolomite $\left[(\mathrm{Ca}, \mathrm{Mg}) \mathrm{CO}_{3}\right]$. The hydrophillic nature of the free silica may also improve soil water retention where necessary. The basic understanding of the mineral dissolution and carbonate precipitation reaction paths has been improved as a result of this characterization study. Some key conclusions include:

- conversion of the silicate to carbonate does not occur in the solid state, but appears to require mineral dissolution into the aqueous phase

- precipitation is the primary mechanism for carbonate formation

- alteration of the primary magnesium silicate minerals produces silica enriched, magnesium depleted intermediate products

- while the mineral dissolution reaction is likely surface controlled, the formation of silica enriched zones suggests the reaction may be diffusion limited

- formation of silica rims on the reaction surfaces may slow further dissolution

- porous, skeletal grains with extremely high silica content were identified in the reaction products, suggesting that with continued removal of $\mathrm{Mg}^{2+}$ cations, the original silicate grains may be converted to masses of amorphous silica

Future studies are intended to investigate various mineral pretreatment options, alternative reactants, scale-up to a continuous process, and process economics.

\section{REFERENCES}

Goff, F., Guthrie, G., Counce, D., Kluk, E., Bergfeld, D., and Snow, M., 1997, "Preliminary Investigations on the Carbon Dioxide Sequestering Potential of Ultramafic

Rocks," Los Alamos, NM, Los Alamos National Laboratory, LA-13328-MS.

Goff, F., Guthrie, G.,Lipin, B., Fite, M., Chipera, S., Counce, D., Kluk, E., and Ziock, H., 2000, "Evaluation of Ultramafic Deposits in the Eastern United States and Puerto Rico as Sources of Magnesium for Carbon Dioxide

Sequestration," Los Alamos, NM, Los Alamos National Laboratory, LA-13694-MS, 36 pp.

Hunter, C. E., 1941, "Forsterite Olivine Deposits of North Carolina and Georgia," Raleigh, NC, North Carolina Department of Conservation and Development, Bulletin 41.

IGCP (International Geological Program), 1977, "North American Ophiolites," Coleman, R. G., and Irwin, W. P., eds., "Ophiolites of continents and comparable oceanic rocks," Portland, OR, State of Oregon, Dept. of Geology and Mineral Industries, Bulletin 95.

Lackner, K. S., Butt, D. P., Wendt, C. H., and Sharp, D. H., 1996, "Carbon Dioxide Disposal in Solid Form," Proc. $21^{\text {st }}$ International Conf. on Coal Utilization and Fuel Systems, Coal Technology Association, Clearwater, Florida.

Lackner, K. S., Butt, D. P., and Wendt, C. H., 1997, "Magnesite Disposal of Carbon Dioxide," Los Alamos, New Mexico, Los Alamos National Laboratory, LA-UR-97660.

O'Connor, W. K., Dahlin, Turner, P. C., and Walters, R.P., 1999, "Carbon Dioxide Sequestration by Ex-Situ Mineral Carbonation,” Technology, Vol. 7S, pp. 115-123.

O’Connor, W. K., Dahlin, D. C., Nilsen, D.N., Rush, G.E., Walters, R.P., and Turner, P. C., 2000, " $\mathrm{CO}_{2}$ Storage in Solid Form: A Study of Direct Mineral Carbonation," Proc. of the $5^{\text {th }}$ International Conference on Greenhouse Gas Technologies, Cairns, Australia, August 14-18, 7 pp. 